\begin{tabular}{|l|l|l|l|l|l|}
\hline JRL & Vol. 14 & No.1 & Hal. 49-59 & $\begin{array}{c}\text { Jakarta, } \\
\text { Juni 2021 }\end{array}$ & $\begin{array}{r}\text { p-ISSN : 2085.38616 } \\
\text { e-ISSN : 2580-0442 }\end{array}$ \\
\hline
\end{tabular}

\title{
OTOMATISASI KONTROL POMPA ULTRAFILTRASI DAN POMPA TEKANAN TINGGI REVERSE OSMOSIS PADA UNIT AIR SIAP MINUM MENGGUNAKAN SCHNEIDER ZELIO SMART RELAY
}

\author{
Imam Setiadi, S.Kom dan Irwan Kustianto, ST \\ Pusat Teknologi Lingkungan, Badan Pengkajian dan Penerapan Teknologi \\ Gedung 820 Geostek, Kawasan PUSPIPTEK, Tangerang Selatan, Banten \\ 15314 \\ imam.setiadi@bppt.go.id, irwan.kustianto@bppt.go.id
}

\begin{abstract}
ABSTRAK
Kebutuhan air minum serta akses untuk mendapatkan air minum yang sehat menjadi kebutuhan dasar yang harus dipenuhi terutama di daerah-daerah yang rawan air. Terutama daerah-daerah yang sulit dijangkau atau tidak mendapat pelayanan air bersih yang disediakan oleh Perusahaan Daerah Air Minum dan lokasi yang secara geografis juga sulit untuk mendapatkan sumber air yang baik. Adanya sarana penyediaan air bersih dengan sistem ultrafiltrasi dan reverse osmosis yang dikembangkan oleh Pusat Teknologi Lingkungan BPPT memungkinkan untuk diterapkan dilokasi-lokasi sulit mendapatkan air, sehingga masalah kesulitan air dapat teratasi. Hanya saja perlu pengelolaan yang baik, serta operator yang cakap, sehingga alat tersebut dapat beroperasi secara berkesinambungan. Kemudahan dalam mengoperasikan, serta otomatisasi menjadi pertimbangan tersendiri terhadap kemudahan dalam pengoperasian alat tersebut. Jenis pompa dan peralatan pengontrol tangkitangki dipilih agar masyarakat tidak sulit mencari suku cadangnya. Untuk mengontrol tangki-tangki air pada sarana penyedia air bersih sistim ultrafiltrasi dan reverse osmosis digunakan teknologi yang sederhana, yaitu radar untuk mengatur tinggi muka air, pressure switch sebagai penunjuk tekanan air, serta PLC Schneider Zelio Smart Relay sebagai pusat kontrolnya. Sistem kontrol radar, pressure switch dan PLC schneider zelio smart relay berharga murah, mudah dalam penerapanya dan dijamin ketersediaan suku cadangnya.
\end{abstract}

Kata kunci: air bersih, ultrafiltrasi, reverse osmosis, otomatis, murah, mudah 


\title{
AUTOMATIZATION OF ULTRAFILTRATION PUMP CONTROL AND REVERSE OSMOSIS HIGH PRESSURE PUMP ON READY TO DRINK WATER UNIT USING SCHNEIDER ZELIO SMART RELAY
}

\begin{abstract}
Drinking water demand and healthy drinking water access are basic needs that must be met, especially in water-prone areas. Especially areas that are difficult to reach or do not get clean water services provided by the Regional Drinking Water Company and locations that are geographically also difficult to get good water sources. The existence of a drinking water supply facility with an ultrafiltration and reverse osmosis system developed by the BPPT Environmental Technology Center allows it to be applied in locations where water is difficult to obtain, so that the problem of water shortages can be resolved. It just needs good management, as well as skilled operators, so that the tool can operate sustainably. Ease of operation, as well as automation is a separate consideration for the ease of operation of the tool. The types of pumps and equipment controlling of the tanks were chosen so that people would not be difficult to find spare parts. To control the water tanks in the ultrafiltration and reverse osmosis system, a simple technology is used, namely a radar to adjust the water level, a pressure switch as a water pressure indicator, and a Schneider Zelio Smart Relay $P L C$ as the control center. The radar control system, pressure switch and PLC Schneider Zelio smart relay are cheap, easy to implement and guaranteed availability of spare parts
\end{abstract}

Keywords: clean water, ultrafiltration, reverse osmosis, automatic, cheap, easy 


\section{PENDAHULUAN}

\subsection{Latar Belakang}

Dengan meningkatnya jumlah penduduk Indonesia pada tiap tahunnya juga meningkatkan akan adanya penyediaan kebutuhan dasar bagi masayarakat baru tersebut, dimana salah satu kebutuhan dasar yang harus dipenuhi adalah ketersediaan air minum yang layak. Kendatipun laju pertumbuhan pertahun mengalami penurunan yaitu sebanyak $1,25 \%$ dimana tercatat pada periode sebelumnya di tahun 2000 - 2010 berada pada angka 1,49\% tapi tetap saja jumlah penduduk Indonesia pada tahun 2020 mencapai 270,2 juta jiwa. (https://www.antaranews.com/berita/19604 64/bps-laju-...) (1)

Dalam rangka memenuhi kebutuhan ketersediaan air minum tersebut maka diperlukan upaya-upaya diseminasi untuk memperkenalkan teknologi penyediaan air siap minum yang handal kepada masyarakat. Terutama untuk daerah-daerah terpencil baik itu pesisir maupun pulau-pulau kecil yang tidak terjangkau oleh layanan Perusahaan Daerah Air Minum.

\subsection{Tinjauan Pustaka}

Penulis dan kawan-kawan telah mengembangkan teknologi penyediaan air siap minum yang merupakan hasil dari kombinasi saringan konvensional dan saringan tingkat lanjut menggunakan membran. Dalam proses penyaringannya, teknologi ini menggunakan pompa-pompa untuk menyalurkan air baku ke dalam saringan untuk menghasilkan air siap minum. Pompo-pompa tersebut adalah sebagai berikut.

\section{a. Pompa umpan Ultrafiltrasi}

Pompa ultrafiltrasi berfungsi mengalirkan air baku dari penampung ke unit penyaringan ultrafiltrasi dan menghasilkan air bersih kemudian meyalurkan air bersih tersebut sebagai umpan pompa reverse osmosis.

\section{b. Pompa umpan reverse osmosis}

Pompa ini dari jenis centrifugal dengan konfigurasi vertical multistage. Pompa ini menerima asupan air bersih dari unit penyaringan ultrafiltrasi dan meneruskan ke dalam membrane reverse osmosis untuk dijadikan air siap minum.

\section{(www.wikikomponen.com,2021)}

\section{c. Kontaktor (Magnetic Contactor)}

Kontaktor adalah peralatan listrik yang bekerja berdasarkan induksi magnetis. Pada bagian dalam kontaktor terdapat kumparan yang jika dialiri listrik maka akan timbul medan magnet pada batang intinya (Sugeng, Yusril, 2014). Akibat dari gaya magnet tadi akan menarik kontak pada bagian atas kontaktor, sehingga kontak normally open akan terhubung, demikian sebaliknya kontak normally close menjadi tidak terhubung.

Komponen penting yang terdapat pada kontaktor adalah sebagai berikut.

1. Kumparan magnet dengan symbol $A 1$ dan A2

2. Tiga pasang kontak utama normally open, 1-2, 3-4, 5-6

3. Dua pasang kontak bantu (auxiliary) 1314 NO, 21-22 NC.

d. Radar

Pada umumnya ada beberapa jenis alat kontrol yang dipakai untuk mengatur operasi pompa, diantaranya pressure switch dan level control. Pressure switch (bekerja berdasarkan tekanan air), sedangan level control (Radar) bekerja berdasarkan ketinggian permukaan air yang berada di dalam tangki.

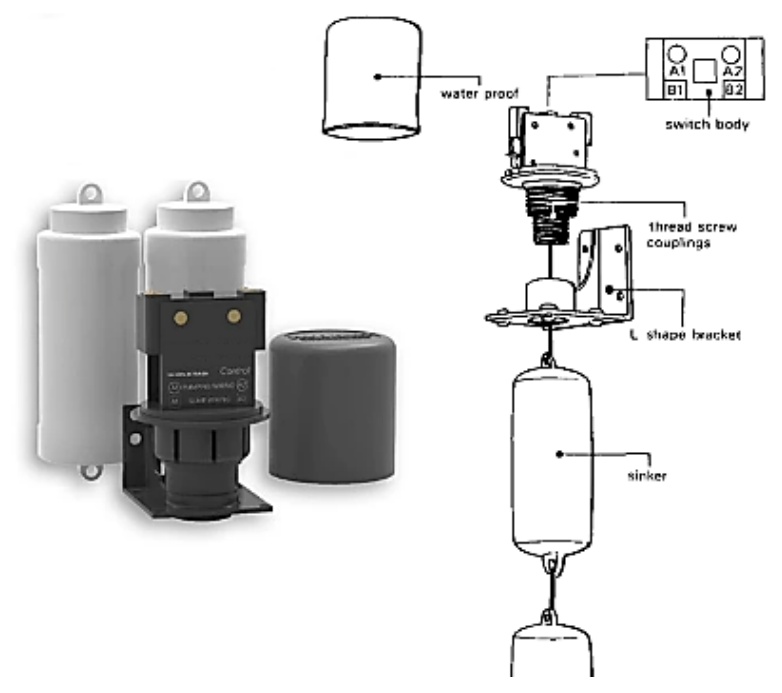

Gambar 1. Model radar yang digunakan 
Pada Gambar 1 di atas maka dapat diketahui bahwa radar tersebut mempunyai 2 buah kontak yaitu A1-A2 dan B1-B2 dimana :

> A1-A2, kondisi normally open

$>$ B1-B2, kondisi normally closed

\section{e. Pressure switch}

Prinsip kerja pressure switch adalah bila tekanan air meningkat, membran akan terdorong ke dalam, berikutnya pegas akan terdorong juga, tuas akan terdorong dan akan mendorong pegas daun, pegas daun yang mendorong tuas terakhir yang akan menutup poin kontak.

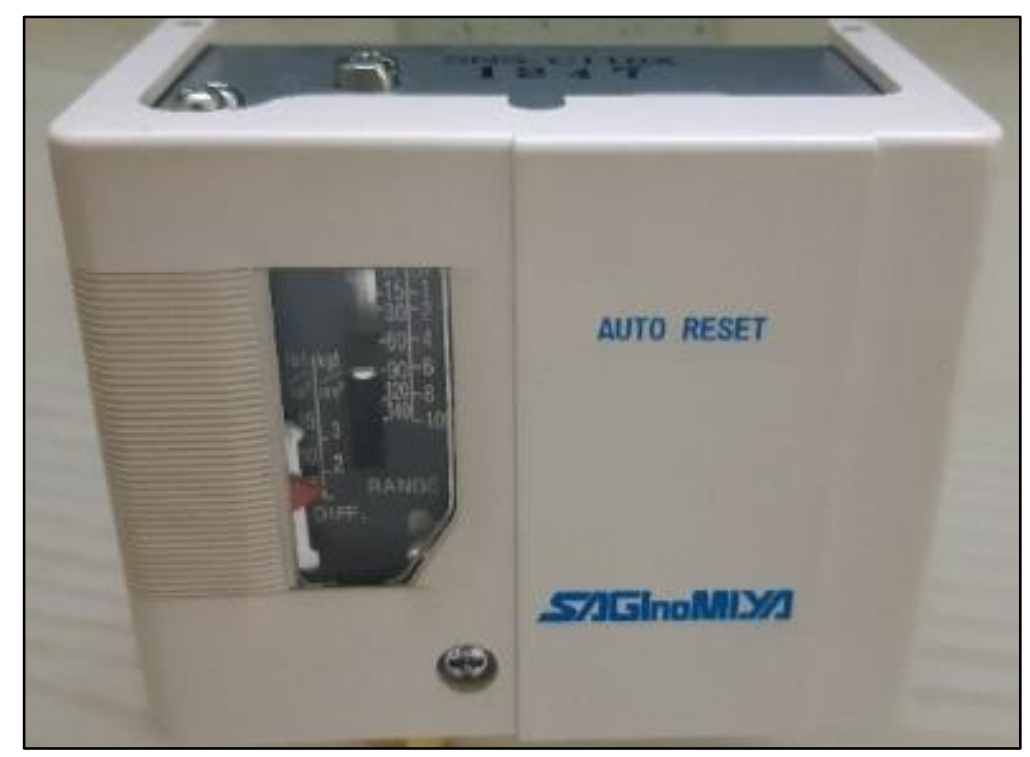

Gambar 2. Pressure switch

Bila ada pemakain air, tekanan air akan berkurang, membran akan tertarik keluar. Pegas spiral juga akan mengembang, tuas akan ikut bergerak, pagas daun akan terdorong juga. Pegas daun akan menarik tuas dan membuka poin kontak.
Pegas daun, berfungsi membedakan antara set point $O N$ dan $O F F$, tekanan yang umum dipakai $2 \mathrm{~kg} / \mathrm{cm} 2$ untuk ON dan $1.8 \mathrm{~kg} / \mathrm{cm} 2$ untuk OFF. Gap ini akan memberikan jeda untuk ON dan OFF. (www.saginomiya.co.jp, 2021)

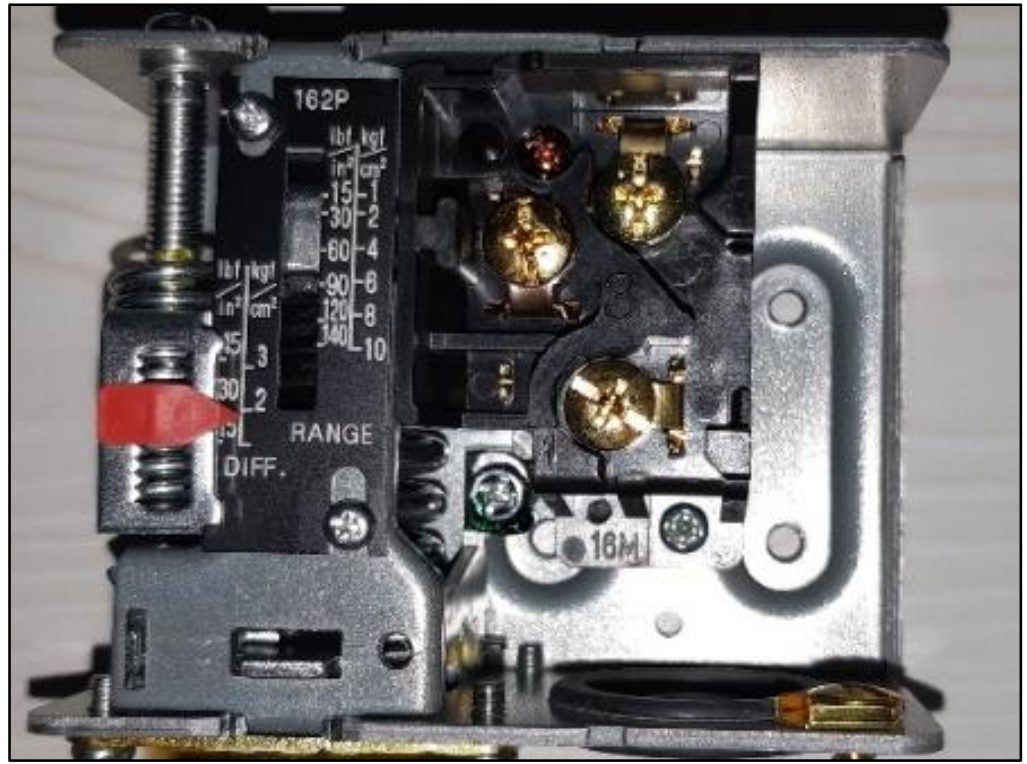

Gambar 2. Bagian dalam terminal pressure switch 
Komponen yang terdapat pada gambar dibawah adalah sebagai berikut.

1. Set point 1 untuk mengatur range tekanan operasi untuk membuka (Off) atau menutup poin kontak (On) pada tekanan tinggi.

2. Set point 2 untuk mengatur diffrential tekanan operasi untuk membuka (Off) atau menutup poin kontak (On) pada tekanan rendah.

3. Mode kontak yang digunakan adalah terminal 1 akan terhubung dengan terminal 3 saat tekanan mencapai 2 $\mathrm{kgf} / \mathrm{cm}^{2}$.

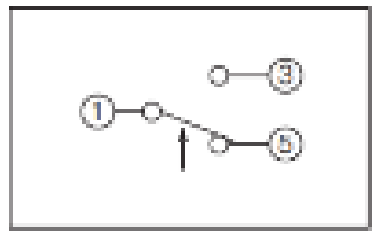

Diagram 1

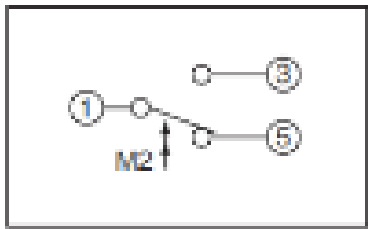

Diagram 2

\begin{tabular}{|c|l|}
\hline & \multicolumn{1}{|c|}{ Diegram 1 \&.2 } \\
\hline 1 & Common Terminal \\
\hline 3 & Close on Pressure increase \\
\hline 5 & Cloce on Pressure Decrease \\
\hline
\end{tabular}

1 : Operating direction on press. increase at High Press. Side M2 $\uparrow$ : Operating direction an manual reset

Gambar 3. Set point tekanan dan terminal

f. Selenoid valve

Solenoid valve merupakan katup yang dikendalikan dengan arus listrik baik $A C$ maupun DC melalui kumparan / selenoida. Solenoid valve ini merupakan elemen kontrol yang paling sering digunakan dalam sistem fluida. Banyak sekali

jenis-jenis dari solenoid valve, karena solenoid valve ini di desain sesuai dari kegunaannya memiliki 2 jenis menurut cara kerjanya, yaitu NC dan NO. Jadi fungsinya hanya menutup / membuka saluran karena

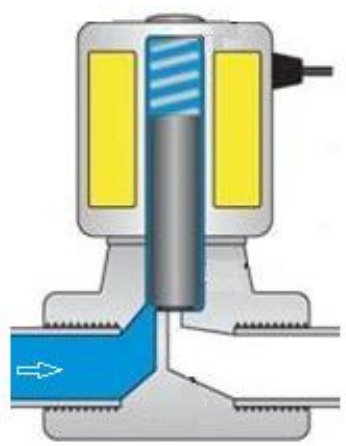

A hanya memiliki 1 lubang inlet dan 1 lubang outlet. Solenoid valve akan bekerja bila kumparan/coil mendapatkan arus listrik dengan tegangan sebesar

100..200VAC pada jenis tegangan arus bolak-balik dan pada tegangan arus searah adalah 12..24VDC. Dan sebuah pin akan tertarik karena gaya magnet yang dihasilkan dari kumparan selenoida tersebut. Dan saat pin tersebut ditarik naik sehingga katup utama terbuka dan fluida mengalir langsung dari saluran inlet ke saluran outlet (www.insinyoer.com, 2021).

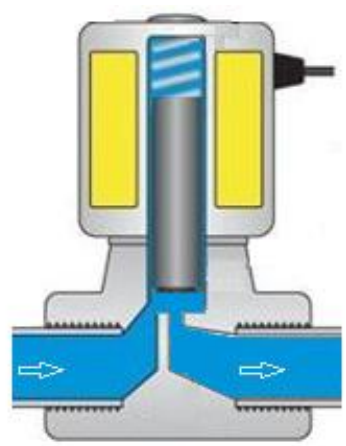

B

Gambar 4. Solenoid valve 


\section{g. Schneider Zelio Smart Relay}

Zelio smart relay adalah suatu alat yang dapat diprogram dengan menggunakan ladder diagram ataupun FBD (Function Blok Diagram) yang bisa digunakan untuk proses otomatisasi. Tujuan diciptakannya zelio smart relay adalah untuk menggantikan logika pengerjaan sirkuit kontrol relay yang merupakan instalasi langsung. Dengan menggunakan smart relay ini maka rangkaian kontrol yang sebelumnya menggunakan relay akan jauh lebih sederhana.

Untuk kegiatan kali ini yang digunakan adalah Schneider Zelio Smart Relay dengan model SR2B201FU. Alat ini mempunyai jumlah input sebanyak 12 dan output sebanyak 8 buah relay. Model SR2B201FU ini bisa diprogram hingga 240 ladder dan 500 FBD. Tegangan input yang digunakan oleh alat ini sebesar 100 sampai 240 VAC (www.se.com, 2021).

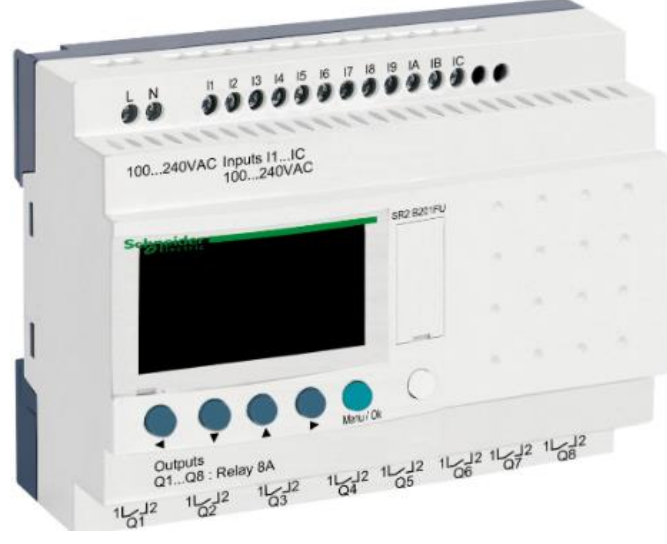

Gambar 5. Zelio Smart Relay

\section{h. Zelio Soft}

Zelio Soft merupakan software yang dipergunakan untuk pemrograman pada Schneider Zelio Smart Relay. Software ini bisa menggunakan 2 bahasa permrograman yaitu ladder dan function blok diagram. Aplikasi ini diinstalasi dan dioperasikan melalui computer desktop ataupun pc. Jika pemorgraman sudah dilakukan maka program tersebut akan dieksport ke dalam memori modul smart relay menggunakan kabel usb pc connecting, dari Schneider (www.se.com, 2021). $\begin{array}{ccr}\text { Untuk } & \text { memudahkan } & \text { saat } \\ \text { pengoperasian } & \text { pompa-pompa tadi }\end{array}$ dibutuhkan satu sistim kontrol yang baik yang dapat menjalankan proses penyaringan secara menyeluruh dan kontinyu. Jika cara-cara lama kontrol ini masih menggunakan metoda yang konvensional dimana kontrol tekanan untuk mengendalikan pompa masih menggunakan relay, maka pada pokok bahasan dibawah ini semua fungsi kontrol relay digantikan dengan fungsi logic modul Schneider Zelio Smart Relay SR2B201FU.

\subsection{Tujuan Penelitian}

Berdasarkan hal tersebut diatas, maka tujuan dari penelitian ini adalah melakukan inovasi otomatisasi kontrol pompa ultrafiltrasi dan pompa tekanan tinggi reverse osmosis menggunakan modul PLC SR2B201FU pada mesin pengolah air siap minum.

\section{METODOLOGI}

Dalam upaya melakukan inovasi otomisasi kontrol pompa ini digunakan aplikasi kombinasi dari :

a. Satu buah pressure switch,

b. Satu buah selenoid valve dengan diameter input dan output 1 inci,

c. Satu buah selenoid valve dengan diameter input dan output $1 / 2$ inci untuk air produk,

d. Satu buah magnetic level kontrol pada tangki air produk,

e. Satu buah level control model pelampung pada tangki pengisian galon serta

f. Satu buah modul plc smart relay sr2b201fu untuk mengontrol seluruh sistim pengolahan air siap minum menggunakan kombinasi membran ultrafiltrasi dan reverse osmosis.

Kondisi kombinasi membran ultrafiltrasi dan reverse osmosis adalah sebagai berikut :

(1) Pompa pretreatment mengalirkan air yang sudah bersih diumpankan ke pompa penyaring ultrafiltrasi. Ketika air menekan pressure switch akan memberi input ke modul zelio smart relay yang memerintahkan selenoid valve membuka katupnya sehingga air dapat 
masuk ke pompa ultrafiltrasi. Jika air tidak menekan pressure switch, indikasi ini menandakan tidak terdapat suplai air dari unit pretreatment sehingga menyebabkan seluruh sistim kendali pengolahan air siap minum tidak berfungsi.

(2) Pada saat yang bersamaan selenoid menutup katupnya sehingga tidak terjadi aliran balik air pada sistim pengolahan air siap minum.

(3) Jika keadaan normal dimana suplai air dari pretreatmen lancar maka proses penyaringan pada membran ultrafiltrasi menghasilkan air yang akan didorong kedalam pompa tekan membran reverse osmosis.

(4) Demi keamanan, pompa tekan reverse osmosis akan hidup 5 detik setelah pompa ultrafiltrasi mengalirkan airnya, kondisi ini untuk memastikan air sudah mengisi tabung pompa dan pompa tidak running dalam kondisi tidak ada air. Seting ini dikendalikan oleh aplikasi timer pada program zelio soft.
(5) Pada saat unit beroperasi dengan normal maka air hasil produksinya akan masuk kedalam tangki produksi melalui selenoid valve produksi, yang terdapat didalam unit pengolahan air siap minum.

(6) Jika tangki air produk sudah penuh maka magnetik level Hi akan memberi sinyal untuk menutup selenoid produk kemudian mengalirkan air produk ke tangki pengisian galon.

(7) Apabila tangki pengisian galon juga sudah penuh maka level kontrol radar pada tangki

akan memberi sinyal untuk menghentikan sistim kendali pengolahan air minum kecuali suplai arus untuk water dispenser.

(8) Pada kondisi dimana level air pada tangki produk pada posisi Low, maka magnetic level akan mengirim sinyal untuk menghidupkan unit pengolahan dan membuka selenoid produk.

Keseluruhan sistem yang digunakan pada unit Arsinum ini bisa dilihat di flow proses pengolahan air siap minum pada gambar 6.

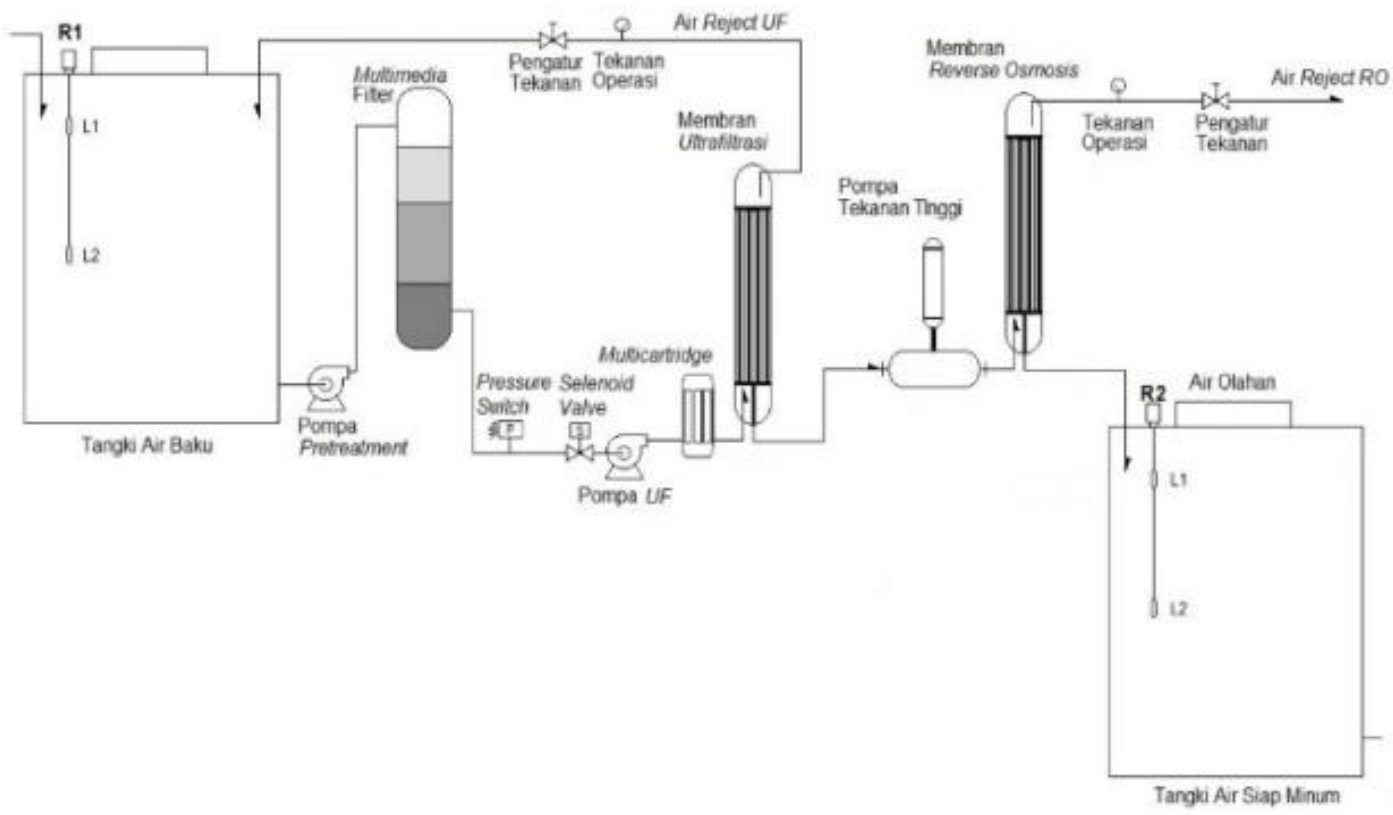

Gambar 6. Flow proses pengolahan air siap minum kombinasi membran ultrafiltrasi dan membran reverse osmosis

\section{HASIL DAN PEMBAHASAN}

Dari sistem arsinum yang digunakan seperti terlihat pada flow proses pengolahan air siap minum pada gambar 6 maka dibuat suatu sistem otomatisasi pengoperasiannya yang menggunakan zelio smart relay 
sebagai pusat kontrolnya yang bisa dilihat pada gambar 7 .

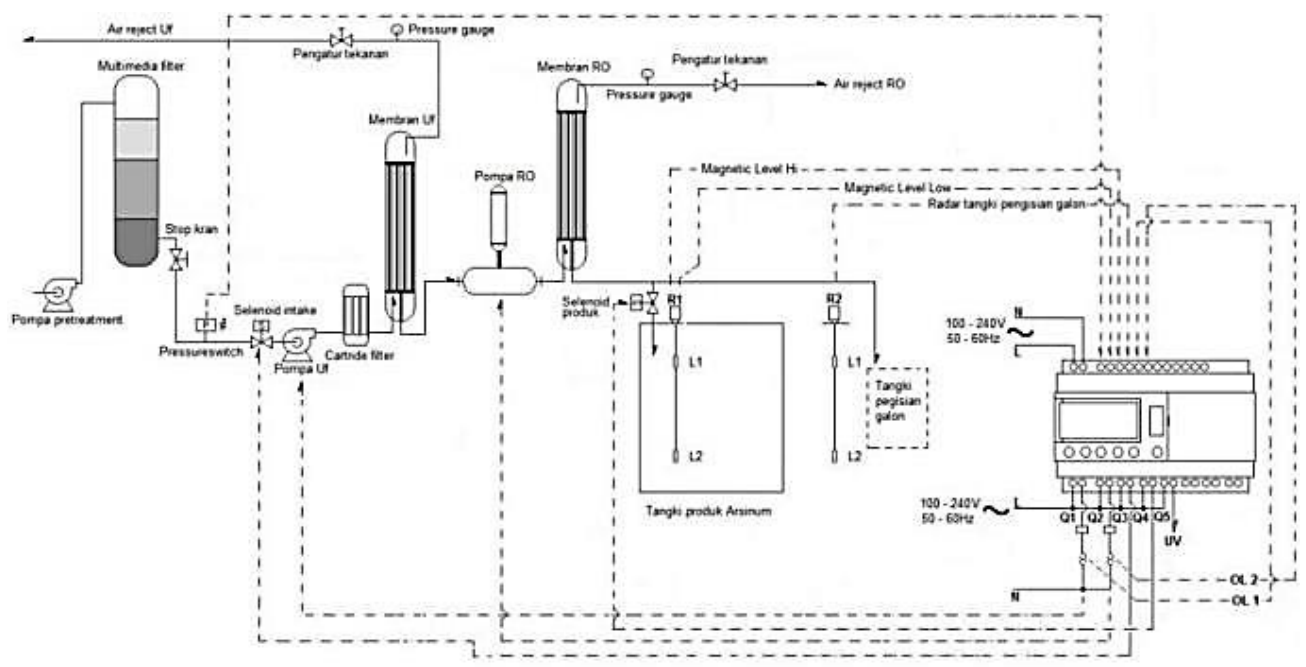

Gambar 7. Wiring diagram pengolahan air siap minum menggunakan kombinasi membran ultrafiltrasidan reverse osmosis

Dengan memperhatikan Gambar 7. maka dapat dijelaskan secara rinci proses otomatisasi pengolahan air siap minum kombinasi membran ultrafiltrasi dan membran reverse osmosis, menggunakan Zelio Smart Relay:

(1) Pompa pretreatment mengalirkan air baku menuju pretreatment filter kemudian mendorong hasil olahannya ke pompa penyaringan unit ultrafiltrasi melewati pressure switch dan solenoid valve.

(2) Seting tekanan batas atas pada pressure switch diseting $2 \mathrm{kgf} / \mathrm{cm}^{2}$, sedangkan untuk diffrencial pada tekanan rendah diseting pada angka $1,7 \mathrm{kgf} / \mathrm{cm}^{2}$.

(3) Pada saat tekanan air mencapai seting batas atas, maka arus listrik pada pressure switch akan mengalir dari poin 1 ke poin 3 . Ini akan memberi input arus listrik pada Zelio Smart Relay SR2 B201FU dan menjalankan program yang menghasilkan output Q1, Q2, Selenoid intake, selenoid produk dan lampu ultraviolet.

(4) Selama tangki produk belum terisi penuh, maka sistim pengolahan air siap minum akan terus beroperasi. Ketika air menyentuh batas atas magnetic level akan memberi instruksi pada selenoid produk untuk menutup katupnya hingga menyebabkan air produk tidak memasuki tangki produk tetapi mengalirkanya ke tangki pengisian galon, sampai tangki pengisian galon penuh.

(5) Jika air tangki pengisian galon penuh akan mengakibatkan sistim pengolahan air minum berhenti beroperasi sampai level air berada dibawah magnetic level ataupun dibawah level radar.

(6) Apabila dalam keadaan tertentu dilakukan backwash pada pretreatment filter, maka stop valve ditutup secara manual sehingga mengakibatkan tidak ada tekanan pada pressure switch kondisi ini juga akan mematikan kendali unit pengolahan air minum.

(7) Sebagai pengaman korsleting pada pompa ultrafiltrasi dan pompa reverse osmosis di pasang pengaman berupa thermal overload yang jika bekerja salah satunya atau 
kedua-keduanya akan memberikan sinyal input pada Zelio Smart Relay untuk meatikan sistim pada program didalam modul.

Skema kontrol otomatisasi yang diaplikasi menggunakan software Zelio Soft dari Schneider merupakan lader diagram yang merupakan bahasa pemrograman universal pada pemrograman PLC. Pemrograman ini mengunakan representasi grafis sebagai acuan kontrolnya seperti kabel listrik, kontak point, magnetic coil dan lain sebagainya untuk kontrol secara logika, seperti yang tampak pada gambar 8 . Adapun program pada PLC ini memerlukan input dari luar seperti saklar, sensor atau perangkat lainya untuk mengeksekusi logika program pada PLC. Sedangkat output yang dikeluarkan dari Zelio Smart Relay merupakan bagian dari PLC yang mengontrol atau mengeksekusi secara analog perangkat luar seperti pompa, swtich relay, alarm dan sebagainya. Pada kegiatan ini table input dan output dapat dilihat pada gambar 9 .

\section{Program diagram}

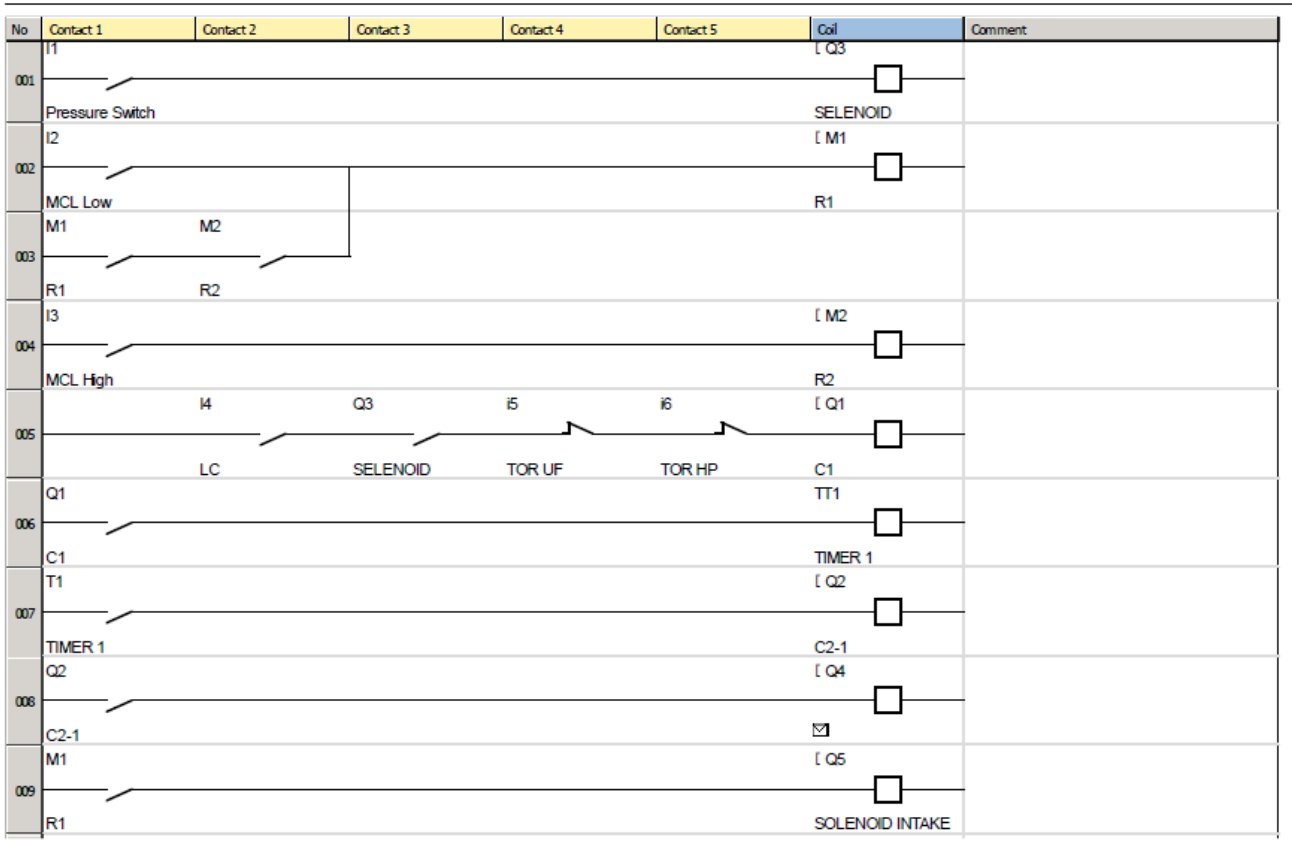

Gambar 8. Kontrol pengolahan air siap minum menggunakan kombinasi membran ultrafiltrasi dan reverse osmosis otomatisasi pada program Zelio Soft smart relay SR2B201FU 


\begin{tabular}{|c|r|l|l|l|l|l|}
\hline No & Symbol & Function & Lock & \multicolumn{1}{|c|}{ Parameters } & Location of (LC) & \multicolumn{1}{|c|}{ Comment } \\
\hline I1 & - I & Discrete inputs & - & No parameters & $(1 / 1)$ & Pressure Switch \\
\hline 12 & - I & Discrete inputs & - & No parameters & $(2 / 1)$ & MCL Low \\
\hline 13 & - I & Discrete inputs & - & No parameters & $(4 / 1)$ & MCL High \\
\hline 14 & - I & Discrete inputs & - & No parameters & $(5 / 2)$ & LC \\
\hline 15 & - I & Discrete inputs & - & No parameters & $(5 / 4)$ & TOR UF \\
\hline 16 & $-I$ & Discrete inputs & - & No parameters & $(5 / 5)$ & TOR HP \\
\hline
\end{tabular}

Physical outputs

\begin{tabular}{|l|c|c|c|l|l|}
\hline No & Symbol & Function & Latching & Location of (LC) & \multicolumn{1}{|c|}{ Comment } \\
\hline Q1 & $\square^{0}$ & Discrete outputs & No & $(5 / 6)(6 / 1)$ & C1 \\
\hline Q2 & $\bigsqcup^{0}$ & Discrete outputs & No & $(7 / 6)(8 / 1)$ & C2-1 \\
\hline Q3 & $\bigsqcup^{0}$ & Discrete outputs & No & $(1 / 6)(5 / 3)$ & SELENOID \\
\hline Q4 & $\bigsqcup^{0}$ & Discrete outputs & No & $(8 / 6)$ & UV \\
\hline Q5 & $\bigsqcup^{0}$ & Discrete outputs & No & $(966)$ & SOLENOID INTAKE \\
\hline
\end{tabular}

Configurable functions

\begin{tabular}{|c|c|c|c|c|c|c|c|}
\hline No & Symbol & Function & Lock & Latching & Parameters & Location of (LC) & Comment \\
\hline M1 & $\square^{\mathrm{M}}$ & Auxiliary relays & - & No & No perameters & $(2 / 6)(3 / 1)(9 / 1)$ & R1 \\
\hline M2 & $\square^{\mathrm{m}}$ & Auxiliary relays & - & No & No perameters & $(3 / 2)(4 / 6)$ & R2 \\
\hline T1 & $y^{*}$ & Timers & No & No & See details below & $(6 / 6)(7 / 1)$ & TIMER 1 \\
\hline
\end{tabular}

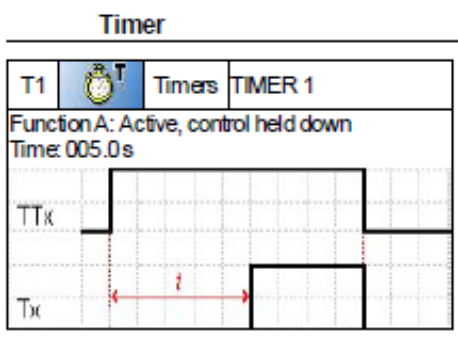

Gambar 9. Tabel input, output dan konfigurasi relay pada program Zelio Soft smart relay SR2B201FU

Dengan dibuatnya sistem otomatisasi pengolahan air siap minum menggunakan zelio smart relay ini menjadikan pengoperasian oleh operator menjadi lebih mudah. Selain itu untuk mendeteksi adanya kerusakan pada sistem ini juga bisa lebih cepat karena semua indikator terpantau pada modul zelio smart relay ini.

\section{KESIMPULAN}

Unit pengolah air siap minum ini terdiri dari beberapa peralatan pompa dan peralatan lainya yang digerakkan oleh tenaga listrik. Kunci dari sistim ini adalah kontrol yang baik untuk mengintegrasikan peralatan-peralatan tersebut sehingga peralatan tersebut tidak menyusahkan operator ketika dioperasikan. Ketersediaan suku cadang di sekitar lokasi instalasi menjadi unsur penting jika terjadi kerusakan, inilah yang menjadi pertimbangan pada saat pemilihan radar komponen untuk mengontrol tangkitangki pada unit ini, terutama pengaman level tangki air produk dan tangki pengisian galon harus higienis karena bersentuhan langsung dengan air minum. Diharapkan dengan aplikasi ini dapat terjadi efisiensi pada pengolahan air minum ini secara keseluruhan sehingga dapat beroperasi secara baik dan terus menerus. 
DAFTAR PUSTAKA

1. (https://www.antaranews.com/berita/19604 64/bps-laju-...)

2. https://www.se.com/id/en/product/SR2USB 5 01/usb-pc-connecting-cable---for-smartrelay-zelio-logic---3-m/

3. http://www.wikikomponen.com/prinsip-dancara-keria-mesin-pompa-air/
4. https://www.saginomiya.co.jp/en/auto/syou sai.php?File $=. /$ pdf/sys. pdf\&Mode $=5 \&$ Name Type $=$ SINGLE\%20FUNCTION\%20PRESS URE\%20CONTROLS\&Type2=sys

https://www.insinyoer.com/prinsip-keriasolenoid-valve/

6. https://www.se.com/id/en/product/SR2B20 1FU/compact-smart-relay-zelio-logic---20-i0---100..240-v-ac---clock---display/ 